\title{
TRANSPARANSI DAN AKUNTABILITAS PELAYANAN PUBLIK KASUS TEKNOLOGI PENGELOLAAN AIR BERSIH DAN AIR LIMBAH DOMESTIK
}

\author{
Komarudin* dan Satmoko Yudo** \\ *Pusat Pengkajian Kebijakan Difusi Teknologi, BPP Teknologi \\ **Pusat Teknologi Lingkungan, BPP Teknologi \\ JI. MH. Thamrin No. 8, Jakarta
}

\begin{abstract}
Bureaucracy reform of public service delivery requires a fast prime, precisely, accurate, and affordable. Some of the important elements of public service delivery, among others, providing guidance services, service standards, service standards at least, one of the doors and a roof, transparency, and accountability. Information on water technology and water management, and need to be provided through public services and the prime quality, transparent and accountable, in order to support efforts to reform the bureaucracy to uphold the principles of good governance.
\end{abstract}

Key words: Transparency and accountability, public services, water and waste water technolgy management.

\section{PENDAHULUAN}

Peran pemerintah saat ini beralih dari "government" ke "governance", dengan mengutamakan pelayanan prima kepada masyarakat. Beberapa kata kunci pelayanan publik prima, antara lain pedoman penyelenggaraan, standar pelayanan, transparansi, akuntabilitas, dan standar pelayanan minimal. Pelayanan publik prima yang berkualitas merupakan salah satu elemen penting dalam penegakan prinsip-prinsip tata pemerintahan yang baik dan reformasi birokrasi.

Pelayanan publik pada hakikatnya adalah pemberian pelayanan prima kepada masyarakat yang merupakan perwujudan kewajiban aparat negara sebagai abdi masyarakat, abdi bangsa, dan abdi negara. Asas pelayanan publik meliputi transparansi, akuntabilitas, kondisional, partisipatif, kesamaan hak, serta keseimbangan hak dan kewajiban. Transparansi adalah bersifat terbuka, mudah dan dapat diakses oleh semua pihak yang membutuhkan dan disediakan secara memadai serta mudah dimengerti. Akuntabilitas adalah dapat dipertanggungjawabkan sesuai ketentuan peraturan perundang-undangan. Ada beberapa kelompok pelayanan publik, antara lain pelayanan administratif, pelayanan barang, dan pelayanan jasa.

Ada sepuluh aspek dalam penyelenggaraan pelayanan publik, yaitu prinsip pelayanan, standar pelayanan, pola penyelenggaraan pelayanan, biaya pelayanan, pelayanan bagi masyarakat tertentu (penyandang cacat, lanjut usia, wanita hamil, dan balita), pelayanan khusus (kelas ekonomi, bisnis, eksekutif, VIP/VVIP), biro jasa pelayanan, tingkat kepuasan masyarakat, pengawasan atas penyelenggaraan pelayanan, serta penyelesaian pengaduan dan sengketa.

Prinsip-prinsip pelayanan publik meliputi kesederhanaan, kejelasan, kepastian waktu, akurasi, keamanan, tanggungjawab, kelengkapan sarana dan prasarana, kemudahan akses, kedisiplinan, kesopanan, keramahan, dan kenyamanan. Standar pelayanan publik sekurang-kurangnya meliputi prosedur, waktu, biaya, produk, sarana dan prasarana, serta kompetensi petugas pemberi pelayanan.

Pola penyelenggaraan pelayanan terdiri atas pola pelayanan fungsional (sesuai dengan tugas, fungsi, dan kewenangan), pola pelayanan terpusat (pelayanan secara tunggal berdasarkan pelimpahan wewenang), pola pelayanan terpadu (satu atap atau satu pintu pada satu tempat yang meliputi berbagai jenis pelayanan), dan gugus tugas (penugasan tertentu dalam memberikan pelayanan).

Biaya pelayanan publik harus memperhatikan tingkat kemampuan dan daya beli masyarakat, nilai/harga yang berlaku atas barang dan/atau jasa, rincian biaya harus jelas untuk jenis pelayanan publik yang memerlukan tindakan seperti penelitian, pemeriksaan, pengukuran dan pengujian, dan ditetapkan oleh pejabat yang berwenang serta memperhatikan prosedur sesuai ketentuan peraturan perundangundangan.

Penyelenggaraan pelayanan wajib mengupayakan tersedianya sarana dan prasarana yang diperlukan serta memberikan akses khusus berupa kemudahan pelayanan bagi penyandang cacat, lanjut usia, wanita hamil dan balita. Penyelenggaraan jenis-jenis pelayanan publik tertentu seperti pelayanan 
transportasi, kesehatan, dimungkinkan untuk memberikan penyelenggaraan pelayanan khusus, dengan ketentuan seimbang dengan biaya yang dikeluarkan sepanjang tidak bertentangan dengan peraturan perundang-undangan, seperti ruang perawatan VIP di Rumah Sakit dan Gerbong Eksekutif pada Kereta Api.

Sebagai wujud partisipasi masyarakat dalam penyelenggaraan pelayanan publik tertentu dimungkinkan adanya biro jasa (seperti dalam penyediaan tiket pesawat terbang). Status biro jasa tersebut harus jelas, memiliki ijin usaha dari instansi berwenang, dan berkoordinasi dengan instansi terkait. Ukuran keberhasilan penyelenggaraan pelayanan ditentukan oleh tingkat kepuasan penerima pelayanan. Kepuasan penerima pelayanan diakibatkan oleh pelayanan sesuai dengan yang dibutuhkan dan diharapkan. Oleh karena itu perlu dilakukan pengukuran indeks kepuasan masyarakat.

Pengawasan atas penyelenggaraan pelayanan publik terdiri atas pengawasan melekat (pengawasan yang dilakukan atasan langsung), pengawasan fungsional (pengawasan yang dilakukan oleh aparat pengawasan fungsional), dan pengawasan masyarakat (pengawasan yang dilakukan oleh masyarakat).

$$
\text { Setiap unit pelayanan wajib }
$$

menyelesaikan setiap laporan/pengaduan masyarakat mengenai ketidakpuasan masyarakat sesuai kewenangannya. Dalam menyelesaikan pengaduan, perlu memperhatikan prioritas penyelesaian pengaduan, penentuan pejabat yang menyelesaikan pengaduan, prosedur penyelesaian pengaduan, rekomendasi penyelesaian pengaduan, pemantauan dan evaluasi, pelaporan proses, penyampaian hasil, dan dokumentasi penyelesaian pengaduan.

\section{TUJUAN DAN SASARAN}

Tujuan dari tulisan adalah untuk mendukung peran lembaga pemerintah dalam memberikan pelayanan kepada masyarakat umum (publik) secara prima, berkualitas, transparan dan akuntabilitas. Kasus yang diambil dalam tulisan ini adalah pelayanan kantor Badan Pengkajian dan Penerapan Teknologi kepada publik tentang teknologi pengelolaan air bersih dan teknologi pengolahan limbah domestik.

Sasaran dari penulisan ini adalah untuk menciptakan lembaga pemerintah dalam penyelenggaran pelayanan publik yang cepat, tepat, akurat, dan terjangkau untuk mendukung upaya reformasi birokrasi dengan menegakkan prinsip-prinsip tata pemerintahan yang baik (good governance).

\section{KAJIAN PUSTAKA}

Dalam kamus Free Dictionary, disebutkan bahwa pelayanan publik adalah bentuk pelayanan yang ditujukan untuk kepentingan masyarakat yang dilakukan oleh organisasi non-profit. Lebih lanjut pelayanan publik juga diartikan sebagai suatu bisnis yang dilakukan untuk memasok kebutuhan pokok seperti air, listrik, atau bisnis yang memberikan pelayanan seperti transportasi dan komunikasi. Pelayanan publik dapat dibedakan menjadi dua jenis. Pertama, pelayanan publik yang penyelenggaraannya dapat dilakukan secara bersama-sama antara pemerintah dan swasta, tetapi kewajiban utama tetap berada di pemerintah. Contoh, pelayanan pendidikan, kesehatan, dan perhubungan. Kedua, pelayanan publik yang hanya dapat dikelola oleh pemerintah, pada umumnya jenis pelayanan ini bersifat pengaturan. Contoh, berbagai bentuk perizinan.

Savas (1987) berdasarkan ciri dasar ekslusi dan konsumsi, mengelompokkan barang dan jasa pelayanan publik, atas barang privat (private good), barang semi privat (common-pool goods), barang semi publik (toll goods), dan barang publik (collective goods).

Reformasi Birokrasi pada dasarnya merupakan peningkatan pelayanan kepada masyarakat untuk mengurangi ketidakpuasan masyarakat dan meningkatkan kualitas pelayanan publik. Pada masa pemerintahan Ronald Reagan di Amerika Serikat dan Margaret Thatcher di Inggris, berkembang model-model reformasi, antara lain New Public Management (NPM), yaitu "a new paradigm for public management has emerged, aimed at fostering performance-oriented culture in a less centralised public sector", yang pada intinya penyelenggaraan pemerintahan menekankan pada prinsip-prinsip:

a. Efisiensi, efektivitas dan kualitas pelayanan;

b. Desentralisasi, dengan pengutamaan pengambilan keputusan pada "point of delivery";

c. Fleksibilitas yang menghasilkan "cost-effective policy outcomes";

d. Penciptaan iklim kompetisi dan produktivitas untuk menghasilkan pelayanan yang efisien;

e. Penguatan kapasitas strategik pemerintah sebagai "steer" (pengatur);

f. Fokus pada penyelarasan kewenangan dan tanggungjawab sebagai kunci peningkatan kinerja; serta

g. Transparansi dan akuntabilitas.

Konsep New Public Management (NPM) kemudian berkembang menjadi New Public Services (NPS) yang mengutamakan pelayanan publik.

Dalam membangun pemerintahan yang efektif, David Osborne (1992) mengembangkan pembaharuan birokrasi ("reinventing 
government') dan pemerintah berjiwa wirausaha ("entrepreneurial government"), dengan membangun:

1. pemerintah berorientasi pelanggan (customer-driven government, meeting the needs of the customers, not the bureaucracy);

2. pemerintah berorientasi misi (mission-driven government, transferring rule-driven organization);

3. pemerintah yang tanggap (anticipatory government, prevention rather than cure);

4. pemerintah berorientasi hasil (result-oriented government, funding outcomes, not inputs);

5. pemerintah yang kompetitif (competitive government, injecting competition into service delivery);

6. pemerintah yang berjiwa wirausaha (entreprising government, earning rather than spending);

7. pemerintah yang terdesentralisasi (decentralized government, from hierarchy to participation and teamwork);

8. pemerintah milik masyarakat (communityowned government, empowering rather than serving);

9. pemerintah katalis (cataytic government, steering rather than rowing); dan

10. pemerintah berorientasi pasar (marketoriented government, leveraging change through the market.

Dalam perkembangannya, pada pertemuan " $7^{\text {th }}$ Global Forum on Reinventing Government, Building Trust in Government," Wina, Austria, 1619 Juni 2007, David Osborne menyodorkan pemikiran "Reinventing Government: What $A$ Difference A Strategy Makes: The Five C's Level Strategy Approaches":

1. Purpose / The Core Strategy / Strategic Management; Clearing the Decks; Uncoupling.

2. Incentives / The Consequences Strategy / Managed Competition; Enterprise Management; Performance Management.

3. Accountability / The Customer Strategy / Customer Choice; Competitive Choice. Customer Quality Assurance.

4. Power / The Control Strategy / Organizational Empowerment; Employee Empowerment; Community Empowerment.

5. Culture / The Culture Strategy / Changing Habits; Touching Hearts; Winning Minds.

Dalam pemikiran ini, tampak menonjol pentingnya kewirausahaan, kinerja, akuntabilitas, pelayanan, pemberdayaan dan perubahan perilaku, budaya, dan mind-set.

Transparansi dan Akuntabilitas, disorot oleh Pan Suk Kim (Korea) dan Emir Mavani (Uni Emirat Arab). "Accountability is a concept in ethics with several meanings. It is often used synonymously with such concepts as answerability, enforcement, responsibility, blameworthiness, liability and other terms associated with the expectation of account-giving. As an aspect of governance, it has been central to discussions related to problems in both the public and private (corporation) worlds. (http://en.wikipedia.org/)

This form of accountability highlights the notion that at the most basic level, accountability is about transparency, about making it possible for actors outside a public organization to identify, and question, what has happened (Shah, Anwar 2007 - World Bank). Accountability International defines 'accountability' as being made up of: a) Transparency: to account to its Stakeholders; b) Responsiveness: to respond to Stakeholder concerns; and c) Compliance: to comply with standards to which it is voluntarily committed, and rules and regulations that it must comply with for statutory reasons (Source: http://www.accountability21.net).

Transparency is "free from pretense or deceit, easily detected or seen through, or readily understood". Why is transparency important? Transparency is essential for democratic decision-making. Citizens must have access to information so that they may participate meaningfully in decision process and make informed choices. Transparansi digambarkan Pan Suk Kim (2007) sebagai berikut:

\section{Unpacking Transparency}

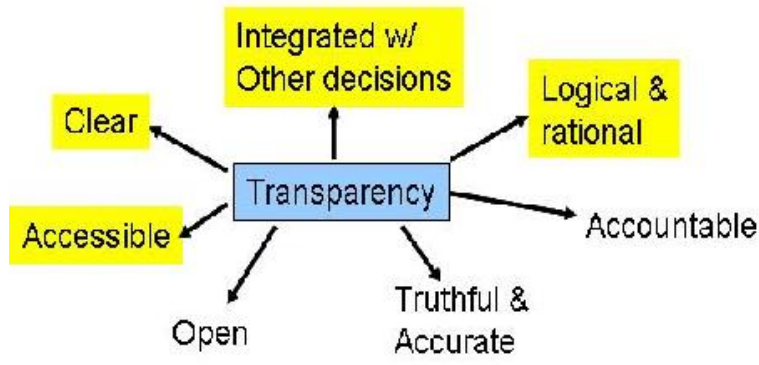

Gambar 1. Transparansi dan akuntabilitas

What is Accountability? "The state of being accountable; The obligation to bear the consequences for failure to perform as expected. Webster's Dictionary defines accountable as responsible or answerable. Accountability is defined as " $A$ is accountable to $B$ when $A$ is obliged to inform $B$ about $A$ 's actions and decisions."

Pan Suk Kim juga membagi transparansi menjadi empat unsur, yaitu "clarity, accessibility, integration, and logic/rationality" sebagaimana diuraikan pada gambar berikut: 


\begin{tabular}{|c|c|}
\hline 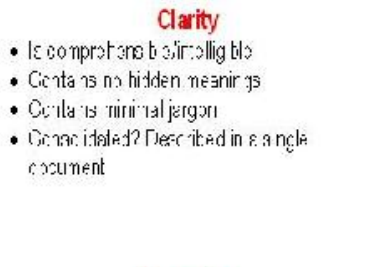 & 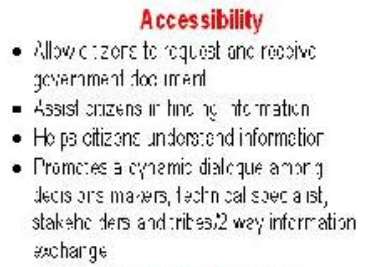 \\
\hline 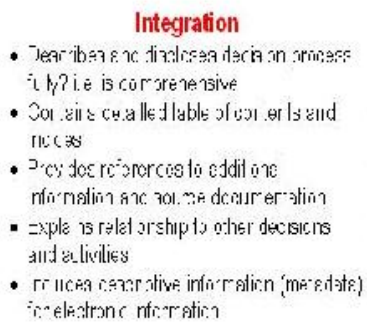 & 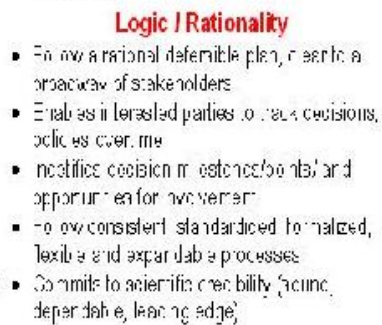 \\
\hline
\end{tabular}

Gambar 2. Empat unsur transparansi

Pan Suk Kim mencatat beberapa hal yang penting diatasi, yaitu kepemimpinan nasional, kesungguhan pemerintah, etika, mindset, cultural-set, prosedur yang kaku, kelemahan dalam penerapan ICT, pendekatan yang kurang terintegrasi, dan reformasi bersifat parsial. Untuk itu, kebijakan harus jelas, sasaran harus jelas, kredibel, reasonable, adanya penghargaan dan sanksi, dan membangun kepercayaan masyarakat terhadap pemerintah." It is often used synonymously with such concepts as answerability (responsibility to someone or for some activity), responsibility, blameworthiness, liability and other terms associated with the expectation of account-giving." Beberapa kata kunci pelayanan publik dalam membangun kepercayaan publik adalah "legality, integrity, efficiency, effectiveness, involvement, participatory, empowerment, dependability, transparency, accountability, and fairness."

Erry Riyana Hardjapamekas menegaskan pentingnya transparansi, akuntabilitas, serta komunikasi dan partisipasi, dan efisiensi dalam penyelenggaraan pelayanan publik. Ismail Mohamad mencatat beberapa kata kunci, antara lain kinerja, etika, budaya kerja, remunerasi, dan profesionalitas.

Sepuluh prinsip good governance yang perlu ditegakkan adalah kesetaraan (equity), pengawasan (supervision), penegakan hukum (law enforcement), daya tanggap (responsiveness), efisiensi dan efektivitas (efficiency and effectiveness), partisipasi (participation), profesionalisme (profesionalism), akuntabilitas (accountability), wawasan ke depan (strategic vision), dan keterbukaan (transparency) - "To Apply Good Governance Principles in Indonesia" menurut Depdagri, UNDP, dan UN-Habitat (2003).

Bappenas melihat ada 14 karakteristik good public governance, yaitu (1) mempunyai wawasan ke depan (strategic vision), (2) terbuka (transparan), keterbukaan/transparansi (transparency); (3) cepat tanggap (responsif), daya tanggap (responsiveness);

Bertanggungjawab dan bertanggunggugat (akuntabel), akuntabilitas (accountability); (5) profesional (profesionalitas, profesionalisme); (6) efisien dan efektif, efisiensi, efektivitas (efficiency, effectiveness), adil, manajemen kepemimpinan yang efektif, dan pelayanan publik yang prima; (7) desentralistis; (8) demokratis; (9) legitimasi; (10) mendorong kemitraan dengan swasta dan masyarakat, kewajaran, kesamaan dan kesetaraan (equity); (11) penegakan hukum (law enforcement); (12) berkomitmen pada pengurangan kesenjangan dan kemiskinan; (13) berkomitmen pada tuntutan pasar, pemanfaatan iptek, peningkatan daya saing, dan peningkatan kualitas SDM; dan (14) berkomitmen pada lingkungan hidup, pembangunan berkelanjutan, berkesinambungan, dan berwawasan lingkungan (Bappenas, UK-ODA, UNDP, WORLD BANK, OECD-DAC).

United Kingdom Overseas Development Administration, UK/ODA, menegaskan bahwa inti good governance adalah legitimasi, akuntabilitas, kompetensi, dan penghormatan terhadap hukum/HAM. United National Development Program, UNDP, menyatakan pentingnya legitimasi politik, kerjasama dengan masyarakat madani (civil society), bebas berasosiasi dan partisipasi, bebas informasi dan ekspresi, akuntabilitas, manajemen efektif dan efisien, sistem yudisial yang adil dan dapat dipercaya, dengan enam ciri, yaitu mengikutsertakan semua, transparan dan bertanggungjawab, efektif dan adil, supremasi hukum, konsensus masyarakat, dan pelibatan masyarakat dalam pengambilan keputusan. World Bank (Bank Dunia), menyarankan masyarakat sipil yang kuat dan partisipatoris, terbuka, kebijakan yang direncanakan, birokrasi profesional, eksekutif yang bertanggungjawab, dan aturan hukum yang jelas. OECD menekankan pentingnya pembangunan partisipatoris, hak asasi manusia, dan demokratisasi (legitimasi, akuntabilitas, pelayanan yang baik, dan komitmen tinggi).

\section{STANDAR PELAYANAN, TRANSPA- RANSI DAN AKUNTABILITAS}

\subsection{Memahami Standar Pelayanan Publik}

Pelayanan publik oleh aparatur negara telah menjadi isu strategis, karena tingkat kualitas kinerja pelayanan publik akan menentukan baik buruknya pelayanan kepada masyarakat dan pada gilirannya akan menentukan citra aparatur negara. Untuk memberikan acuan bagi instansi pemerintah 
pusat dan daerah dalam penyusunan standar pelayanan publik, telah ditandatangani Peraturan Menteri Negara Pendayagunaan Aparatur Negara Nomor PER/20/M.PAN/04/2006 tentang Pedoman Penyusunan Standar Pelayanan Publik.

Permenpan ini berisi enam bagian, yaitu pengertian umum, prinsip penyusunan, komponen, langkah penyusunan, pemantauan dan pengendalian, dan lembar kerja. Pedoman ini bertujuan mendorong tersusunnya standar pelayanan publik pada setiap unit pelayanan agar penyelenggaraan pelayanan publik berjalan lebih baik. Beberapa pengertian dalam pedoman ini adalah pelayanan publik, standar pelayanan publik, manajemen pelayanan, penyelenggaraan pelayanan, dan instansi pemerintah, pembina teknis, unit pelayanan, pemberi pelayanan, penerima pelayanan, dan biaya pelayanan.

Prinsip penyusunan standar pelayaan publik meliputi konsensus, sederhana, konkrit, mudah diukur, terbuka, terjangkau, dapat dipertanggungjawabkan, mempunyai batas waktu pencapaian, dan berkesinambungan. Konsensus, artinya standar pelayanan yang ditetapkan merupakan komitmen dan hasil kesepakatan bersama antara pimpinan dan staf unit pelayanan dengan memperhatikan sungguh-sungguh kepentingan pihak yang berkepentingan serta mengacu pada norma atau peraturan yang telah ada. Sederhana, artinya standar pelayanan yang ditetapkan memuat aturan yang bersifat pokok sehingga mudah dipahami dan dilaksanakan, baik oleh petugas pemberi layanan maupun oleh masyarakat. Konkrit, artinya standar pelayanan yang ditetapkan bersifat nyata dan jelas untuk dilaksanakan. Mudah diukur, standar pelayanan yang ditetapkan dapat diukur implementasinya, baik teknis maupun nonteknis. Terbuka, standar pelayanan yang ditetapkan bersifat terbuka untuk mendapatkan saran dan masukan bagi upaya penyempurnaan.

Terjangkau, penerima layanan tidak keberatan dan standar pelayanan dapat dilaksanakan secara baik dan benar, baik oleh pemberi maupun penerima layanan. Dapat dipertanggungjawabkan, hal-hal yang diatur dalam standar pelayanan dapat dipertanggungjawabkan secara nyata kepada pihak-pihak yang berkepentingan (akuntabel, akuntabilitas). Mempunyai batas waktu pencapaian, standar pelayanan dapat memberikan ketetapan waktu bagi pencapaian hal-hal yang telah diatur dalam standar pelayanan. Berkesinambungan, standar pelayanan dapat terus menerus disempurnakan sesuai dengan perkembangan dan tuntutan peningkatan kualitas pelayanan.

Komponen standar pelayanan publik meliputi jenis, dasar hukum, persyaratan, prosedur, waktu penyelesaian, biaya, dan produk pelayanan, serta sarana dan prasarana, dan mekanisme penanganan pengaduan. Selain prinsip tersebut, ada faktor pendukung yang harus diperhatikan, yaitu kompetensi petugas pemberi pelayanan dan mekanisme pengawasan. Jenis pelayanan adalah pelayanan-pelayanan yang dihasilkan oleh unit penyelenggara pelayanan. Dasar hukum pelayanan adalah peraturan perundang-undangan yang menjadi dasar penyelenggaraan pelayanan. Persyaratan pelayanan, yaitu syarat-syarat yang harus dipenuhi dalam pengurusan sesuatu jenis pelayanan, baik teknis maupun administratif. Prosedur pelayanan, yaitu tata cara pelayanan yang dibakukan bagi pemberi dan penerima pelayanan termasuk pengaduan.

Waktu penyelesaian pelayanan adalah jangka waktu yang diperlukan untuk menyelesaikan seluruh proses pelayanan dari setiap jenis pelayanan. Biaya pelayanan adalah besaran biaya/tariff pelayanan yang harus dibayarkan oleh penerima pelayanan. Produk pelayanan adalah hasil pelayanan yang akan diterima sesuai dengan ketentuan yang telah ditetapkan. Sarana dan prasarana adalah fasilitas yang diperlukan dalam penyelenggaraan pelayanan, termasuk fasilitas pelayanan bagi penyandang cacat. Mekanisme penanganan pengaduan adalah tata cara pelaksanaan penanganan pengaduan sesuai dengan ketentuan.

Kompetensi petugas pemberi pelayanan sebagai faktor pendukung adalah kemampuan yang harus dimiliki oleh petugas, meliputi pengetahuan, keahlian, keterampilan, sikap, dan perilaku. Mekanisme pengawasan adalah tata cara pelaksanaan pengawasan sesuai dengan ketentuan.

Ada sebelas langkah penyusunan standar pelayanan publik. Pertama, inventarisasi tugas dan fungsi setiap unit pelayanan, baik utama atau pendukung termasuk dasar hukum penyelenggaraan pelayanan publik. Kedua, inventarisasi pengguna/penerima layanan guna mengetahui jenis pelanggarn, besaran tarif, dan klasifikasi pelayanan. Ketiga, survai harapan masyarakat (secara periodik, minimum sekali dalam setahun) untuk mengetahui harapan dan keinginan masyarakat terhadap pelayanan yang diberikan.

Keempat, analisis prosedur pelayanan (bagan alir) yang dilakukan dengan mengidentifikasi seluruh aktivitas pelayanan secara berurutan dimulai saat penerima pelayanan datang sampai dengan produk/hasil pelayanan. Bagan alir ini harus mencerminkan tata urut pelayanan, mekanisme kerja, persyaratan legalitas, jelas dan pasti, informatif, dan visualisasi tempat dan nama petugas pelayanan. 
Kelima, analisis persyaratan pelayanan yang ada dan mengkaji persyaratan yang baru untuk memperbaharui kebijakan. Identifikasi dimaksud hendaknya memperhatikan substansi pelayanan, aktivitas yang jelas, tahapan yang jelas, sifat dan karakteristik jenis pelayanan, dan menghilangkan segala persyaratan yang bersifat duplikasi dengan instansi terkait.

Keenam, analisis waktu penyelesaian dengan mengamati pengalaman, harapan penerima pelayanan, dan kemampuan internal petugas pemberi pelayanan, dilakukan melalui survai efisiensi, efektivitas, dan produktivitas. Penetapan waktu penyelesaian pelayanan harus memperhatikan jumlah personil yang tersedia, sarana dan prasarana pelayanan yag dimiliki, beban kerja, tahapan proses pelayanan, kemampuan dan keterampilan SDM pelayanan, dan keterkaitan proses pelayanan dengan instansi lain.

Ketujuh, analisis biaya pelayanan meliputi kemampuan ekonomi, harapan penerima pelayanan, dan tingkat kesulitan pelayanan. Penetapan biaya pelayanan memperhatikan besaran biaya yang layak, kemampuan ekonomi masyarakat, tidak bertentangan dengan peraturan perundang-undangan, dan tingkat kesulitan proses pelayanan dan kegunaan/manfaat produk pelayanan.

Kedelapan, analisis sarana dan prasarana pelayanan yang dilakukan dengan identifikasi kebutuhan utama dan pendukung yang dibutuhkan pemberi dan penerima pelayanan Sarana pelayanan adalah sarana yang harus disesuaikan dalam proses pelayanan (formulir, fasilitas pengolahan data, dan telekomunikasi). Prasarana pelayanan adalah fasilitas yang disediakan dalam mendukung pelayanan, antara lain ruang tunggu, kamar kecil, sarana parkir, dan tempat sampah. Analisis sarana dan prasarana pelayanan memperhatikan jenis, jumlah, kualitas, dan pemanfaatan serta kemampuan keuangan.

Kesembilan, analisis personalia dengan melihat jumlah beban kerja, jenis kegiatan, tingkat kesulitan, ketersediaan sarana dan prasarana, agar diperoleh pemberi pelayanan yang mampu melaksanakan tugas pelayanan dengan baik dan lancar. Hal-hal yang harus diperhatikan, antara lain jumlah beban kerja dikaitkan dengan formasi personil, jenis kegiatan dikaitkan dengan kualifikasi pendidikan, tingkat kesulitan proses pelayanan dikaitkan dengan keahlian dan keterampilan, serta ketersediaan sarana dan prasarana dikaitkan dengan sifat dan jenis pelayanan.

Kesepuluh, analisis pengawasan dan pola pengawasan agar penyelenggaraan pelayanan publik dapat dikendalikan dan diawasi oleh pimpinan unit pelayanan maupun masyarakat penerima layanan. Analisis pengawasan memperhatikan penyelenggaraan pelayanan apakah sesuai dengan standar pelayanan, pemantauan terus menerus, dan evaluasi penerapan standar pelayanan apakah sesuai dengan kebutuhan penerima layanan.

Kesebelas, analisis penanganan pengaduan yang dilaksanakan dengan memperhatikan keluhan yang disampaikan penerima layanan, dengan menyediakan sarana pengaduan, petugas khusus yang menangani, dan tindak lanjut pengaduan secara cepat sesuai peraturan perundang-undangan, Penanganan dan tindak lanjut pengaduan masyarakat memperhatikan penatausahaan, proses pembuktian pengaduan dengan melakukan konfirmasi dan klarifikasi, penelitian, pemeriksaan dan pelaporan hasil penelitian/ pemeriksaan. Tindak lanjut dan pemantauan pengaduan masyarakat meliputi tindak lanjut hasil penelitian/pemeriksaan, pemanfaatan hasil penanganan pengaduan masyarakat, pemantauan dan koordinasi penanganan pengaduan masyarakat, dan pemberian sanksi.

Pimpinan unit penyelenggara pelayanan publik harus melakukan pemantauan, evaluasi, pengawasan dan pengendalian kualitas pelayanan. Penerapan standar pelayanan perlu terus menerus dipantau implementasinya. Pemantauan tidak hanya terkait dengan sejauh mana pelayanan telah memenuhi standar pelayanan yang ditetapkan, tetapi juga terkait dengan aspek-aspek manajemen sejauh mana unit pelayanan secara konsisten menghasilkan pelayanan yang sesuai dengan standar pelayanan dimaksud. Jika dari proses pemantauan diperoleh penyimpangan, maka dengan cepat pihak unit pelayanan dapat melakukan tindakan pengendalian agar proses pelayanan tetap menghasilkan pelayanan yang sesuai dengan standar pelayanan.

Pemantauan dan pengendalian sangat perlu dilakukan, antara lain karena adanya kecenderungan perubahan masyarakat pelanggan yang selalu menghendaki perbaikan kualitas pelayanan dari waktu ke waktu, perubahan lingkungan internal dan eksternal serta perkembangan teknologi. Upaya pemantauan dan pengendalian juga dilakukan dengan menghimpun masukan dari masyarakat, baik melalui pengaduan masyarakat maupun survai untuk melihat sejauh mana diwujudkan kepuasan masyarakat. Juga dapat dilakukan melalui pemberian penghargaan dan sanksi (reward and punishment) untuk menjaga dan memotivasi seluruh jajaran pegawai agar tetap taat pada aturan yang ditetapkan untuk menjamin konsistensi pelayanan. Diharapkan tercipta peningkatan kualitas pelayanan dan kepuasan masyarakat/pelanggan dan tercipta pelayanan 
prima yang berkualitas yang menegakkan standar pelayanan publik dan kepentingan masyarakat penerima pelayanan.

Lembar Kerja (bersifat dinamis) terdiri atas dua jenis. Pertama, lembar kerja identifikasi jenis pelayanan, dibuat untuk memudahkan proses identifikasi tentang jenis pelayanan yang memuat unit pelayanan, jenis pelayanan yang diberikan dan dasar hukum. Kedua, lembar kerja identifikasi analisis proses dan prosedur, persyaratan, sarana dan prasarana, waktu dan biaya pelayanan.

Ada lima catatan penutup. Pertama, penetapan standar pelayanan publik untuk setiap jenis pelayanan dilakukan oleh pembina teknis unit pelayanan sesuai dengan peraturan perundang-undangan berdasarkan usulan pimpinan unit pelayanan yang bersangkutan setelah melakukan pembahasan dengan masyarakat yang berkepentingan dan tenaga ahli yang berkaitan dengan jenis pelayanan.

Kedua, dengan ditetapkannya pedoman penyusunan standar pelayanan publik ini hendaknya disosialisasikan kepada masyarakat agar masyarakat mengetahui keberadaan standar pelayanan tersebut sehingga dalam penerapannya masyarakat dapat ikut berpartisipasi dalam mengawasinya. Ketiga, keberhasilan penyusunan standar pelayanan di lingkungan instansi pemerintah ditentukan oleh komitmen pembina teknis unit pelayanan publik beserta pimpinan instansi yang memberikan pelayanan kepada masyarakat.

Keempat, dalam merealisasikan standar pelayanan publik, setiap unit pelayanan publik disarankan dan didorong untuk menetapkan, mendokumentasikan, dan memelihara sistem manajemen pelayanan publik serta secara terus menerus meningkatkan keefektifannya. Kelima, dalam rangka pelaksanaan penyusunan standar pelayanan publik, pembina teknis pelayanan publik yang bersangkutan dapat melakukan konsultasi dengan Menteri yang bertanggungjawab di bidang pendayagunaan aparatur negara.

Selanjutnya diharapkan agar pemahaman tentang standar pelayanan publik yang ditetapkan dengan Permenpan ini, dapat dijadikan sebagai bahan pembuatan standar pelayanan publik sebagaimana ditetapkan dalam Undang-Undang tentang Pelayanan Publik.

\subsection{Transparansi dan Akuntabilitas Pelayanan Publik}

Transparansi dan akuntabilitas pelayanan publik merupakan hal yang sangat penting dalam penyelenggaraan pelayanan publik untuk menciptakan kualitas pelayanan publik. Transparansi dan akuntabilitas dalam penyelenggaraan pelayanan publik sebagaimana diatur dalam Keputusan Menpan Nomor KEP/26/M.PAN/2/2004 utamanya diwujudkan pada aspek pembiayaam, waktu, persyaratan, prosedur, informasi, pejabat yang berwenang dan bertanggungjawab, mekanisme pengaduan masyarakat, standar, dan lokasi pelayanan. Transparansi dan akuntabilitas pelayanan publik harus dilaksanakan pada seluruh aspek manajemen pelayanan publik meliputi kebijakan, perencanaan, pelaksanaan, pengawasan dan pengendalian, dan pelaporan hasil kinerja.

Keputusan Menpan ini dimaksudkan untuk meningkatkan transparansi dan akuntabilitas pelayanan publik yang meliputi pelaksanaan prosedur, persyaratan teknis dan administratif, biaya, waktu, akta atau janji atau maklumat, motto pelayanan, lokasi, standar pelayanan, informasi dan pejabat yang berwenang atau yang bertanggungjawab dalam penyelenggaraan pelayanan publik.

Transparansi

penyelenggaraan pelayanan publik merupakan pelaksanaan tugas dan kegiatan yang bersifat terbuka bagi masyarakat, mulai dari proses kebijakan, perencanaan, pelaksanaan, pengawasan dan pengendalian, yang mudah diakses oleh semua pihak yang membutuhkan informasi. Untuk itu perlu dipelajari dan dipahami Undang-Undang Nomor 14 Tahun 2008 tentang Keterbukaan Informasi Publik. Transparansi dalam penyelenggaraan pelayanan publik utamanya meliputi sepuluh elemen, yaitu manajemen dan penyelenggaraan pelayanan publik, prosedur pelayanan, persyaratan teknis dan administratif pelayanan, rincian biaya pelayanan, waktu penyelessaian pelayanan, pejabat yang berwenang dan bertanggungjawab, lokasi pelayanan, janji pelayanan, standar pelayanan publik, dan informasi pelayanan.

Transparansi terhadap manajemen dan penyelenggaraan pelayanan publik (harus dapat diinformasikan dan mudah diakses oleh masyarakat) meliputi kebijakan, perencanaan, pelaksanaan, pengawasan dan pengendalian oleh masyarakat. Prosedur pelayanan adalah rangkaian proses atau tatacara yang berkaitan satu sama lain, sehingga menunjukkan adanya tahapan secara jelas dan pasti serta cara-cara yang harus ditempuh dalam rangka penyelesaian suatu pelayanan. Prosedur pelayanan harus sederhana, tidak berbelit-belit, mudah dipahami, dan mudah dilaksanakan serta diwujudkan dalam bentuk Bagan Alir (Flow Chart) yang dipampang dalam ruangan pelayanan.

Bagan alir sangat penting dalam penyelenggaraan pelayanan publik, karena berfungsi sebagai petunjuk kerja pemberian pelayanan, informasi bagi penerima pelayanan, media publikasi secara terbuka pada setiap unit 
kerja pelayanan, pendorong terwujudnya sistem dan mekanisme kerja yang efektif dan efisien, dan pengendali/alat kontrol dan acuan bagi masyarakat dan aparat pengawasan untuk melakukan penilaian dan pemeriksaan terhadap konsistensi pelaksanaan kerja pelayanan. Bagan alir harus mampu menggambarkan proses pelayanan, petugas pelayanan, pejabat yang bertanggungjawab untuk setiap tahapan pelayanan, unit kerja terkait, waktu, dan dokumen yang diperlukan, dimulai dari penerimaan berkas permohonan sampai dengan selesainya proses pelayanan. Model bagan alir dapat dibuat berbentuk bulat atau kotak dengan tanda panah yang jelas. Ukuran bagan alir disesuaikan dengan luas ruangan, ditulis dengan huruf cetak dan mudah dibaca dalam jarak pandang tiga meter, dan bagan alir diletakkan pada tempat yang mudah dilihat oleh penerima pelayanan.

Peryaratan teknis dan administratif pelayanan, harus seminimal mungkin dan merupakan hasil kajian agar benar-benar sesuai dengan jenis pelayanan. Harus dihilangkan aturan yang bersifat duplikasi. Persyaratan harus diinformasikan secara jelas dan diletakkan dekat loket pelayanan, ditulis dengan huruf cetak dan dapat dibaca dalam jarak pandang tiga meter atau disesuaikan dengan kondisi ruangan. Rincian biaya pelayanan adalah rincian segala biaya dengan nama atau sebutan apapun sebagai imbalan atas pemberian pelayanan, ditetapkan oleh pejabat yang berwenang sesuai ketentuan peraturan perundang-undangan. Rincian biaya harus jelas, ditulis dengan huruf cetak diletakkan dekat loket pelayanan. Transparansi biaya dilakukan dengan mengurangi semaksimal mungkin pertemuan secara personal antara pemohon/penerima pelayanan dengan petugas pemberi pelayanan. Unit kerja pelayanan seyogyanya tidak menerima pembayaran secara langsung dari penerima pelayanan. Sebaiknya pembayaran dilakukan melalui petugas pengelola keuangan atau perbankan. Setiap pungutan harus disertai bukti resmi penerimaan.

Waktu penyelesaian pelayanan adalah jangka waktu penyelesaian suatu jenis pelayanan publik mulai dari dilengkapinya atau dipenuhinya persyaratan teknis dan/atau persyaratan administratif sampai dengan selesainya proses pelayanan. Dalam memberikan pelayanan, digunakan nomor urut permintaan pelayanan. Yang pertama kali mengajukan pelayanan harus lebih dahulu dilayani dan diselesaikan segera apabila persyaratannya lengkap (First In First Out atau FIFO). Kepastian dan kurun waktu pelayanan publik harus diinformasikan secara jelas kepada penerima pelayanan.
Pejabat atau petugas yang berwenang dan bertanggungjawab memberikan pelayanan dan/atau menyelesaikan keluhan/persoalan/ sengketa, diwajibkan memakai tanda pengenal dan papan nama di meja atau tempat kerja petugas. Pejabat atau petugas dimaksud harus ditetapkan dengan Surat Penugasan. Petugas pemberi pelayanan harus menegakkan citra positif terhadap penerima pelayanan, dengan memperhatikan aspek psikologi dan komunikasi serta perilaku melayani, empathi terhadap penerima pelayanan, mengubah keluhan menjadi senyuman, berbicara sopan, menyesuaikan nada, tekanan dan kecepatan suara, sikap tubuh, mimic dan pandangan mata, mengenal siapa dan apa yang menjadi kebutuhan penerima pelayanan, dan berada di tempat yang ditentukan pada waktu dan jam pelayanan.

Tempat dan lokasi pelayanan diusahakan harus tetap dan tidak berpindahpindah, mudah dijangkau oleh pemohon pelayanan, dilengkapi sarana dan prasarana yang memadai termasuk sarana telekomunikasi dan informatika (telematika). Untuk memudahkan masyarakat dalam memperoleh pelayanan, dapat dibentuk unit pelayanan terpadu (satu pintu atau satu atap) atau pos pelayanan di tempat tertentu (kelurahan/desa/kecamatan). Akta atau janji pelayanan (juga disebut maklumat pelayanan) merupakan komitmen tertulis unit kerja pelayanan dalam menyediakan pelayanan kepada masyarakat sesuai dengan standar pelayanan. Janji pelayanan ditulis secara jelas, singkat dan mudah dimengerti, menyangkut halhal esensial dan informasi akurat, termasuk standar kualitas pelayanan. Juga dapat dibuat "motto pelayanan" untuk memberikan semangat, dan kepastian pelayanan. Akta atau janji ini harus diinformasikan dan ditulis dengan huruf cetak, mudah dibaca dalam jarak pandang tiga meter atau disesuaikan dengan kondisi ruangan.

Standar pelayanan publik harus dibuat dan dipublikasikan kepada masyarakat sebagai jaminan kepastian pelayanan. Standar pelayanan publik merupakan ukuran kualitas kinerja yang dibakukan dalam penyelenggaraan pelayanan publik yang wajib ditaati oleh pemberi dan/atau penerima pelayanan. Standar pelayanan harus realistis, merupakan jaminan bahwa janji atau komitmen yang dibuat dapat dipenuhi, jelas dan mudah dimengerti oleh pemberi dan penerima pelayanan. Setiap unit pelayanan wajib menginformasikan dan mempublikasikan prosedur, persyaratan, biaya, waktu, standar, akta/janji, motto pelayanan, lokasi, dan pejabat/petugas yang berwenang dan bertanggungjawab sebagaimana diuraikan di atas. Publikasi dilakukan antara lain melalui media cetak (brosur, leaflet, booklet), media elektronik (website, home-page, situs internet, 
radio, dan televise), media gambar dan/atau penyuluhan dan sosialisasi secara langsung kepada masyarakat.

Penyelenggaraan pelayanan publik harus dapat dipertanggungjawabkan (akuntabel, akuntabilitas), baik kepada publik maupun kepada atasan/pimpinan unit pelayanan sesuai ketentuan peraturan perundang-undangan. Pertanggungjawaban pelayanan publik meliputi akuntabilitas kinerja, biaya, dan produk pelayanan publik. Akuntabilitas kinerja pelayanan publik dapat dilihat berdasarkan proses antara lain meliputi tingkat ketelitian (akurasi), profesionalitas petugas pemberi pelayanan, kelengkapan sarana dan prasarana, kejelasan aturan (kebijakan) dan kedisiplinan. Akuntabilitas kinerja pelayanan publik harus sesuai dengan standar pelayanan publik atau akta/janji pelayanan publik. Standar pelayanan publik harus dapat dipertanggungjwabkan secara terbuka. Jika terjadi penyimpangan dalam pencapaian standar, harus diupayakan perbaikan. Jika ini terjadi, harus diberikan kompensasi kepada penerima pelayanan. Masyarakat dapat melakukan penilaian terhadap kinerja pelayanan secara berkala sesuai mekanisme yang berlaku dan harus disediakan mekanisme pertanggungjawaban jika terjadi kerugian dalam pelayanan publik. Setiap pengaduan masyarakat harus ditangani dan ditindaklanjuti dengan cepat.

Akuntabilitas biaya dikaitkan atau ditunjukkan dengan biaya pelayanan yang dipungut sesuai dengan ketentuan peraturan perundang-undangan. Biaya pelayanan publik harus transparan dan masuk akal, terjangkau dan tidak memberatkan penerima pelayanan. Akuntabilitas produk pelayanan publik didasarkan atas persyaratan teknis dan administratif yang harus jelas dan dapat dipertanggungjawabkan baik dari segi kualitas maupun keabsahan produk pelayanan. Prosedur dan mekanisme kerja harus sederhana dan tidak memberatkan penerima pelayanan. Produk pelayanan harus diterima dengan benar, tepat dan sah. Produk pelayanan diupayakan memenuhi kebutuhan dan kepuasan penerima pelayanan.

Untuk memperoleh umpan balik dari masyarakat atas pelayanan yang diberikan, perlu disediakan akses kepada masyarakat untuk memberikan informasi, saran, pendapat, tanggapan, pengaduan (complaint) dalam bentuk kotak pengaduan, kotak pos atau satuan tugas penerima pengaduan yang berfungsi menerima dan menyelesaikan pengaduan masyarakat. Setiap orang yang menyampaikan pengaduan, baik tertulis maupun langsung kepada pejabat/petugas penerima pengaduan, diberikan surat atau formulir tanda bukti pengaduan, dengan menyebutkan nama dan pejabat atau petugas yang berwenang menyelesaikan pengaduan dan jangka waktu penyelesaian.

Masukan dari masyarakat, baik berupa infomasi, saran, pendapat, tanggapan dan/atau pengaduan, hendaknya ditindaklanjuti dengan langkah upaya perbaikan pelayanan oleh unit pelayanan. Jika dalam pengaduan terdapat masyarakat yang dirugikan, perlu dipertimbangkan pemberian kompensasi. Pengaduan tertulis baik melalui surat maupun media elektronik, harus disampaikan secara jelas dan bertanggungjawab dengan menyebutkan nama, alamat yang jelas, dan identitas yang sah, bukan merupakan surat kaleng. Jika dalam pengaduan ternyata terjadi penyimpangan oleh petugas pemberi pelayanan, maka kepadanya perlu diberikan sanksi sesuai ketentuan peraturan perundang-undangan.

Ada lima catatan penting tentang transparansi dan akuntabilitas pelayanan publik. Pertama, untuk memberikan motivasi kepada para penyelenggara pelayanan publik dalam mewujudkan transparansi dan akuntabilitas pelayanan publik, dapat diadakan semacam perlombaan dan pemberian penghargaan bagi unit kerja pelayanan yang menunjukkan prestasi kerja yang baik dan diberikan sanksi kepada unit pelayanan publik yang mempunyai kinerja pelayanan rendah. Kedua, untuk mengukur tingkat transparansi dan akuntabilitas penyelenggaraan pelayanan publik, digunakan pengukuran Indeks Kepuasan Masyarakat yang diatur dalam Kepmenpan Nomor KEP/25/M.PAN/2/2004 tentang Pedoman Umum Penyusunan Indeks Kepuasan Masyaraat Unit Pelayanan Instansi Pemerintah.

Ketiga, upaya perbaikan pelayanan publik harus dilakukan secara terus menerus dan berkelanjutan, serta disesuaikan dengan perkembangan perubahan situasi dan kondisi. Keempat, penerapan teknologi informasi (egovernment) oleh instansi pemerintah dapat menjadi alat bantu yang penting dalam melaksanakan transparansi dan akuntabilitas pelayanan publik. Kelima, dalam rangka meningkatkan perlindungan hak-hak masyarakat agar memperoleh pelayanan umum, keadilan dan kesejahteraan secara lebih baik, dapat bekerjasama dengan lembaga pengawasan masyarakat dan Ombudsman (sebagaimana ditetapkan dalam Undang-Undang Nomor 37 Tahun 2008 tentang Ombudsman Republik Indonesia). Transparansi dan akuntabilitas pelayanan publik merupakan bagian dari tujuh asas penyelenggaraan negara yang bersih dan bebas dari KKN (kepastian hukum, tertib penyelenggaraan negara, kepentingan umum, keterbukaan, proporsionalitas, profesionalitas, dan akuntabilitas) sebagaimana ditetapkan dalam Undang-Undang Nomor 28 Tahun 1999 
tentang Penyelenggaraan Negara yang Bersih dan Bebas dari KKN.

\subsection{Formulasi dan Evaluasi Kinerja Kebijakan Publik}

Kebijakan penyelenggaraan pelayanan publik, termasuk standar pelayanan, transparansi dan akuntabilitas, merupakan bagian dari kebijakan publik. Pedoman Umum Formulasi, Implementasi, Evaluasi Kinerja dan Revisi Kebijakan Publik di lingkungan lembaga pemerintah pusat dan daerah, diatur dengan Peraturan Menteri Negara Pendayagunaan Aparatur Negara Nonor PER/04/M.PAN/4/2007 yang berisi, antara lain pengertian umum, prinsip penyusunan kebijakan publik, bentuk, stratifikasi dan sifat kebijakan publik, langkah-langkah formulasi, implementasi, dan evaluasi kinerja kebijakan publik.

\section{STANDAR PELAYANAN MINIMAL}

Tindak lanjut Pasal 11 ayat (4) dan Pasal 14 ayat (3) Undang-Undang Nomor 32 Tahun 2004 Tentang Pemerintahan Daerah adalah diterbitkannya Peraturan Pemerintah Nomor 65 Tahun 2005 tentang Pedoman Penyusunan dan Penerapan Standar Pelayanan Minimal (SPM) yang merupakan acuan bagi Pemerintah dalam penyusunan SPM dan menjadi pokok-pokok acuan bagi Pemerintahan Daerah dalam penerapan SPM yang disusun oleh Pemerintah.

SPM adalah ketentuan tentang jenis dan mutu pelayanan dasar yang merupakan urusan wajib daerah yang berhak diperoleh setiap warga secara minimal. Indikator SPM adalah tolok ukur presentasi kuantitatif dan kualitatif yang digunakan untuk menggambarkan besaran sasaran yang hendak dipenuhi dalam pencapaian suatu SPM tertentu, berupa masukan, proses, hasil dan/atau manfaat pelayanan. Pelayanan Dasar adalah jenis pelayanan publik yang mendasar dan mutlak untuk memenuhi kebutuhan masyarakat dalam kehidupan sosial, ekonomi dan pemerintahan. Prinsip-prinsip SPM adalah sederhana, konkrit, mudah diukur, terbuka, terjangkau dan dapat dipertanggungjawabkan serta mempunyai batas waktu pencapaian.

\section{TRANSPARANSI DAN AKUNTA- BILITAS PELAYANAN TEKNOLOGI PENGELOLAAN AIR BERSIH DAN LIMBAH CAIR}

Kelompok Teknologi Pengelolaan Air Bersih dan Limbah Cair, Bidang Pengendalian Pencemaran Lingkungan, Pusat Teknologi Lingkungan, TPSA-BPPT adalah salah satu bagian di lembaga pemerintah non departemen (BPPT) yang memberikan pelayanan kepada publik atau masyarakat luas khususnya mengenai permasalahan tentang air bersih dan limbah cair. Pelayanan diberikan secara langsung baik melalui tatap muka, telepon, maupun melalui media cetak dan elektronik (koran, majalah, tabloid, tv, radio, email, internet, dan lain-lain).

Untuk menambah pemahaman kepada para pengambil keputusan dan praktisi industri tentang teknologi pengelolaan air bersih dan teknologi pengolahan limbah cair diadakan pelatihan secara periodik setiap tahun. Pameran dan workshop adalah salah satu sarana untuk menyampaikan hasil-hasil kajian dan aplikasi yang telah dilakukan kelompok tersebut selama ini kepada masyarakat luas. Dalam pameran tersebut ditampilkan poster, banner, brosur tentang semua teknologi yang telah di dikaji dan aplikasikan serta beberapa unit teknologi pengolahan air bersih dan limbah cair.

Sarana untuk memudahkan masyarakat dalam mencari atau mengakses informasi tentang teknologi pengelolaan air bersih dan limbah cair dapat dilihat pada website di www.kelair.bppt.go.id.

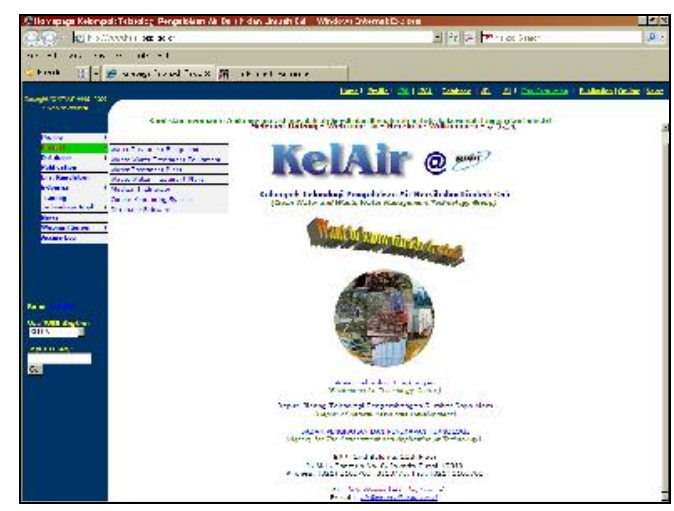

Gambar 3. Tampilan muka website teknologi pengolahan air bersih dan limbah cair

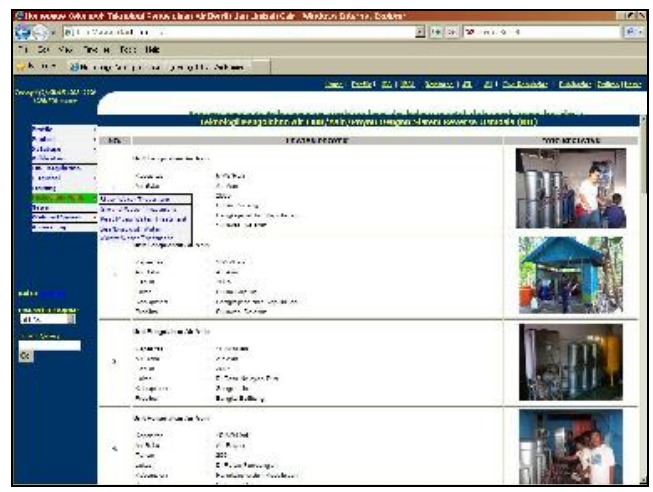

Gambar 4. Contoh dalam website berisi beberapa aplikasi teknologi pengolahan air asin siap minum 
Dalam website ini berisi informasi tentang produk dan aplikasi teknologi air bersih dan limbah cair, database tentang sistem informasi sumberdaya air, sistem informasi teknologi pengolahan air, sistem informasi kualitas air sungai, Jurnal Teknologi Lingkungan, Jurnal Air Indonesia, himpunan Peraturan Perundangan Bidang Lingkungan, publikasi dan pelatihan serta lainnya.

\subsection{Penyediaan Air Bersih di Indonesia}

Nusa Idaman Said dan Satmoko Yudo (2008) dalam tulisannya berjudul "Masalah dan Strategi Penyediaan Air Bersih di Indonesia", menegaskan bahwa penyediaan air bersih untuk masyarakat mempunyai peranan yang sangat penting dalam meningkatkan kesehatan lingkungan atau masyarakat, yaitu mempunyai peranan dalam menurunkan angka penderita penyakit, khususnya yang berhubungan dengan air dan berperan dalam meningkatkan standar atau taraf/kualitas hidup masyarakat.

Transparansi dan akuntabilitas pelayanan publik tentang penyediaan air bersih, antara lain :

a. Informasi tentang PDAM Kabupaten/Kota (manajemen, SDM, PAD, tarif, pelayanan, kehilangan/kebocoran, profesionalitas, tugas dan fungsi terkait, dan hubungan dengan pejabat pemerintah daerah).

b. Pelayanan air bersih, kualitas dan kuantitas air baku (fluktuatif pada musim hujan),

c. Penggunaan air tanah dan air sungai, serta sumur resapan.

d. Teknologi pengolahan air minum (konvensional menggunakan sistem koagulasi-flokulasi/pengendapan kimia, saringan pasir cepat/rapid sand filter, dan proses disinfeksi menggunakan senyawa khlorin/gas khlor).

e. Biaya produksi air minum, harga jual air minum, dan daya beli masyarakat.

f. Ketersediaan sumber air baku air minum (debit air sungai/danau dan air tanah).

g. Kandungan zat besi atau zat mangan di dalam air yang masih cukup tinggi.

h. Kebijakan pembangunan air minum (UUD NRI 1945, RPJMN 2005-2009, Millennium Development Goals/MDG, dan Deklarasi Kyoto/World Water Forum 2003).

i. Kebijakan pengelolaan air minum (berbasis lembaga, berbasis lembaga dan masyarakat, dan berbasis masyarakat).

j. Kebijakan berbasis masyarakat (air sebagai benda sosial dan benda ekonomi, pemenuhan kebutuhan dasar, perilaku hidup bersih dan sehat, keberpihakan pada masyarakat miskin, peran serta dan partisipasi perempuan, peran pemerintah sebagai fasilitator, peran serta dan partisipasi aktif masyarakat, pelayanan optimal dan tepat sasaran, penerapan prinsip pemulihan biaya (cost recovery), dan pembangunan berwawasan lingkungan.

k. Transparansi pelayanan dan akuntabilitas aparat pelayanan (desentralisasi, masyarakat sebagai subyek pembangunan di samping sebagai obyek pembangunan, sistem pengelolaan, dari-oleh-untuk masyarakat, dan peluang kepada semua pihak untuk berkontribusi mulai perencanaan sampai ke pelaksanaan, pemeliharaan dan pengembangan).

I. Aspek-aspek pembangunan air minum (kelembagaan, SDM, teknik, pembiayaan, sosial, dan lingkungan hidup).

m. Strategi pelaksanaan pembangunan air minum (peraturan perundang-undangan, kesisteman, investasi, pembiayaan, sarana, prasarana, fasilitas, efektivitas, efisiensi, kualitas hidup masyarakat, kemampuan masyarakat, norma - standar - pedoman manual atau disingkat NSPM, penelitian dan pengembangan, motivasi masyarakat, kepedulian, pelayanan terhadap kelompok masyarakat tertentu, pelestarian, keberlanjutan, pemantauan dan evaluasi, serta pengendalian dan pengawasan).

\subsection{Pengolahan Air Bersih dengan Proses Saringan Pasir Lambat}

Teknologi saringan pasir lambat (Sarpalam) merupakan teknologi pengolahan air yang sangat sederhana yang dapat menghasilkan air bersih dengan kualitas yang baik. Sarpalam dibagi menjadi tiga jenis, yaitu aliran dari atas ke bawah (down flow), dari bawah ke atas (up flow), dan kombinasi keduanya.

Teknologi yang dikembangkan BPPT adalah penyaringan dengan aliran dari bawah ke atas (up flow).

Pengolahan air bersih dengan menggunakan sistem saringan pasir lambat "Up Flow" mempunyai keuntungan antara lain :

a. Tidak memerlukan bahan kimia, sehingga biaya operasinya sangat murah.

b. Dapat menghilangkan zat besi, mangan, dan warna serta kekeruhan.

c. Dapat menghilangkan ammonia dan polutan organik, karena proses penyaringan berjalan secara fisika dan biokimia.

d. Proses operasi dan perawatannya murah dan mudah.

e. Sangat cocok untuk daerah pedesaan karena proses pengolahan sangat sederhana.

Konstruksinya dapat dibuat sederhana, biaya relatif rendah, dan hasilnya cukup baik. 
Transparansi dan akuntabilitas teknologi Sarpalam, antara lain:

a. Informasi sistem Sarpalam (saluran bawah, saluran atas, lapisan pasir, ventilasi, dan keran).

b. Informasi elemen dan bagian peralatan (inlet, lapisan air di atas media penyaring, bagian pengeluaran/outlet, media pasir, sistem saluran bawah, dan ruang pengeluaran).

c. Informasi tentang proses pengolahan (hasil uji performance; penghilangan kekeruhan, zat besi, ammonium, dan zat organik).

d. Informasi hasil pengolahan Sarpalam (data kualitas air hasil sebelum pengolahan dan sesudah pengolahan)

a. Informasi tentang pengalaman penerapan teknologi Sarpalam (Pesantren La Tansa, Lebak, Jawa Barat, Desa Dantar, Kecamatan Padang Cermin, Teluk Ratai, Lampung)

e. Keterbukaan dalam pengelolaan anggaran perawatan alat.

f. Informasi spesifikasi peralatan yang digunakan (Ukuran beton, perpipaan, bahan material, dll.)

g. Kontribusi masyarakat mulai perencanaan lokasi penempatan alat, pembangunan bangunan pelindung, pengelolaan operasi dan pemeliharaan alat.

h. Jaminan kerusakan alat selama 1 tahun dan konsultasi pemecahan masalah selamanya.

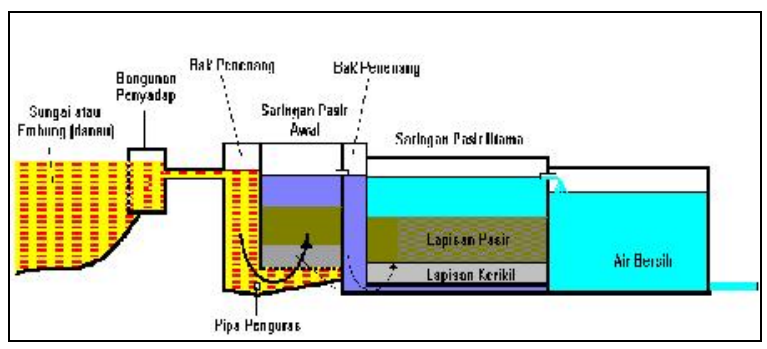

Gambar 5. Diagram proses pengolahan air bersih Saringan Pasir Lambat Up Flow Kapasitas $100 \mathrm{M}^{3} /$ Hari.

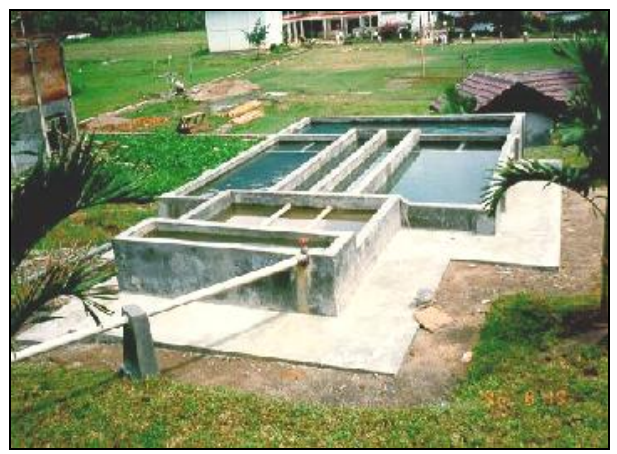

Gambar 6. Unit pengolahan air bersih saringan pasir lambat Up Flow, kapasitas $100 \mathrm{M}^{3} /$ hari. Lokasi : Pesantren La Tansa, Lebak, Jawa Barat.

\section{a. Pengolahan Air Minum untuk Penduduk di Daerah Pesisir}

Tujuan utama dari pembangunan sarana air minum ini adalah untuk memenuhi kebutuhan air minum untuk masyarakat di daerah-daerah yang sulit air tawar seperti daerah di kawasan pesisir pantai dan daerah kepulauan. Teknologi pengolahan air minum ini menggunakan teknologi pengolahan air asin sistem osmosis balik (reverse osmosis)

Transparansi dan akuntabilitas teknologi pengolahan air asin sistem $\mathrm{RO}$, antara lain:

a. Informasi teknologi pengolahan air asin (sistem pengolahan, diagram alir pengolahan, proses pengolahan.)

b. Spesifikasi komponen peralatan (pompa, tangki kontaktor, filter, dosing pump, unit RO)

c. Kontribusi masyarakat mulai perencanaan lokasi penempatan alat, pekerjaan bangunan pelindung, pengelolaan operasi dan pemeliharaan alat.

d. Informasi biaya produksi air minum, harga jual air dan kemampuan daya beli masyarakat.

e. Petunjuk operasional pemakaian alat (SOP, Panduan, Manual, Troubleshooting).

f. Pelatihan dan cara perawatan kepada pengelola alat dan masyarakat setempat.

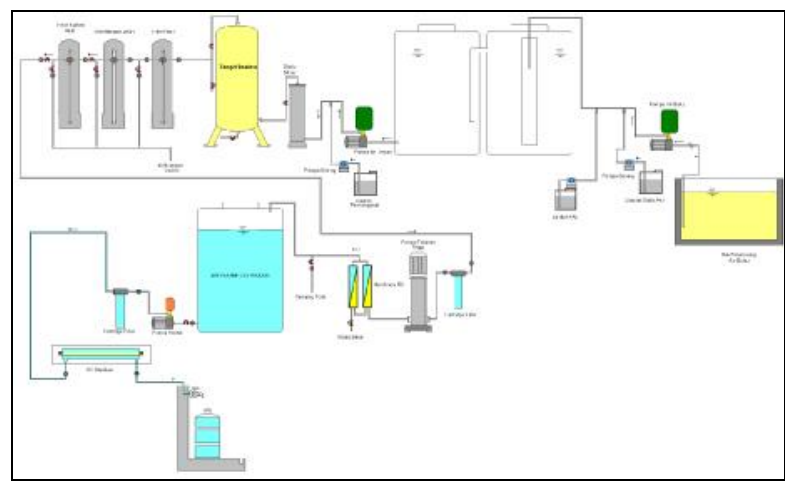

Gambar 7. Diagram proses pengolahan air minum sistem reverse osmosis

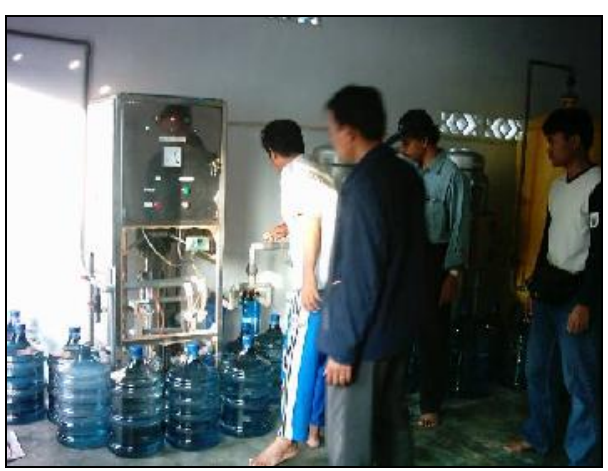

Gambar 8. Peralatan pengolah air siap minum 


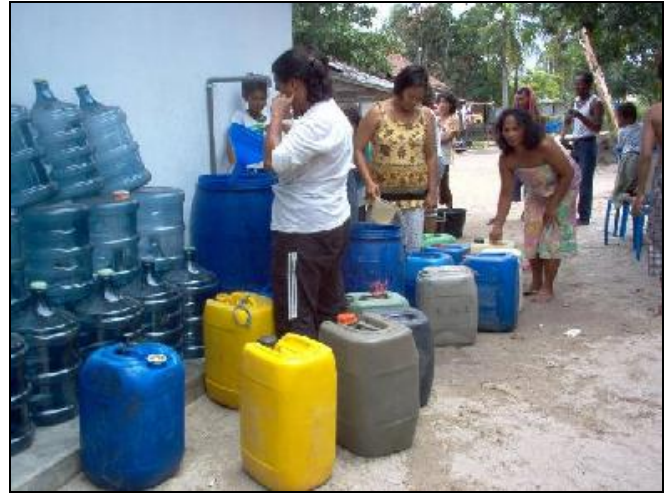

Gambar 9. Antrian air minum penduduk

\section{b. Teknologi Pengolahan Air Limbah Domestik}

Teknologi pengolahan air limbah domestik untuk rumah tangga adalah teknologi untuk mengatasi masalah pencemaran oleh air limbah rumah tangga dengan cara mengolah air limbah rumah tangga tersebut secara individual ataupun secara komunal (on Site Treatment) sebelum dibuang ke saluran umum.

Instalasi pengolahan air limbah (IPAL) rumah tangga ini dapat dibuat dari bahan batu bata atau beton cor atau bahan fiberglas, tergantung dari situasi, kondisi, harga bahan baku serta kemudahan pemasangannya.

Transparansi dan akuntabilitas teknologi pengolahan air limbah domestik untuk rumah tangga, antara lain:

a. Informasi teknologi pengolahan air limbah domestik untuk rumah tangga (proses pengolahan, diagram pengolahan, cara pembuatan dan perawatan)

b. Bahan baku konstruksi dan spesifikasi peralatan yang digunakan.

c. Kebijakan Peraturan Gubernur DKI Jakarta Nomor 122 tahun 2005 tentang Pengelolaan Air Limbah Domestik di Provinsi Daerah Khusus Ibukota Jakarta.

d. Kebijakan mengolah air limbah sebelum dibuang ke saluran umum.

e. Kandungan BOD \& COD, deterjen, ammonia, bakteri E.Coli yang cukup tinggi dalam air limbah domestik yang belum diolah.

f. Efisiensi penghilangan BOD, COD dan padatan tersuspensi (SS) cukup tinggi, yakni lebih dari $90 \%$.

g. Pelatihan dan Diseminasi teknologi pengolahan air limbah domestik kepada masyarakat.

h. Pembuatan prototipe pengolahan air limbah domestik untuk didiseminasi dan dikembangkan masyarakat.

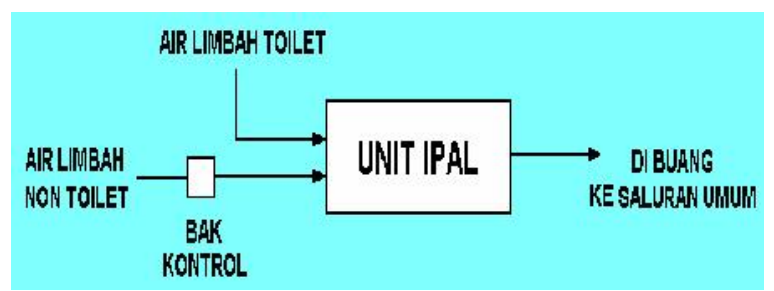

Gambar 10. Diagram alir proses pengolahan air limbah rumah tangga

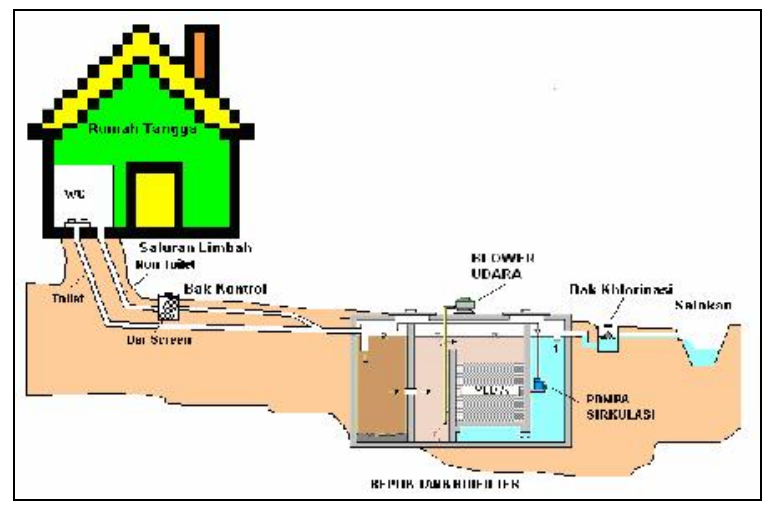

Gambar 11. Lokasi penempatan IPAL domestik untuk rumah tangga

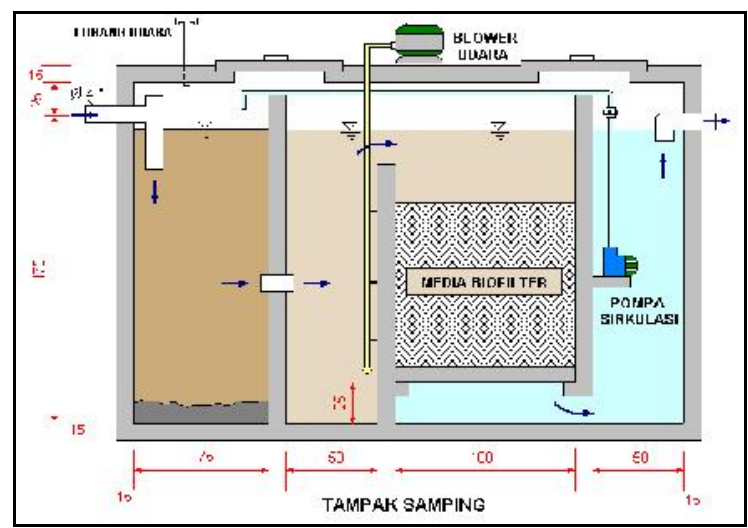

Gambar 12. Diagram bak reaktor IPAL domestik untuk skala rumah tangga

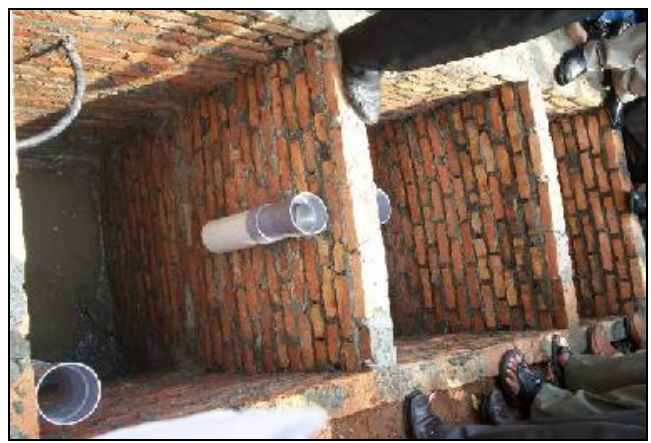

Gambar 13. Konstruksi dan bahan pembuatan IPAL dari batu bata 


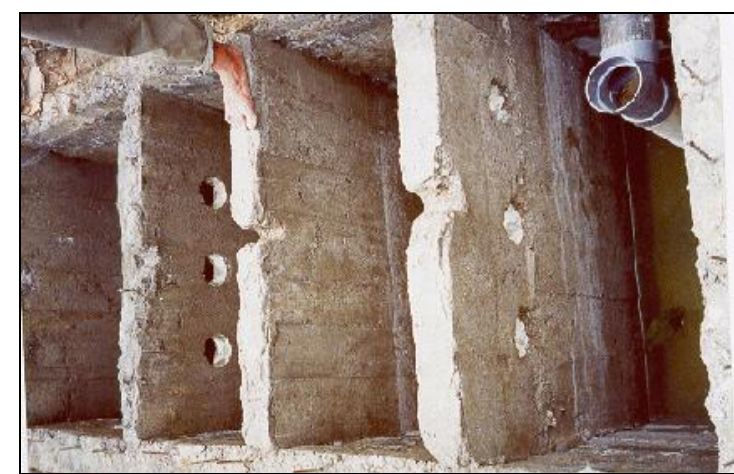

Gambar 14. Konstruksi dan bahan pembuatan IPAL dari beton cor

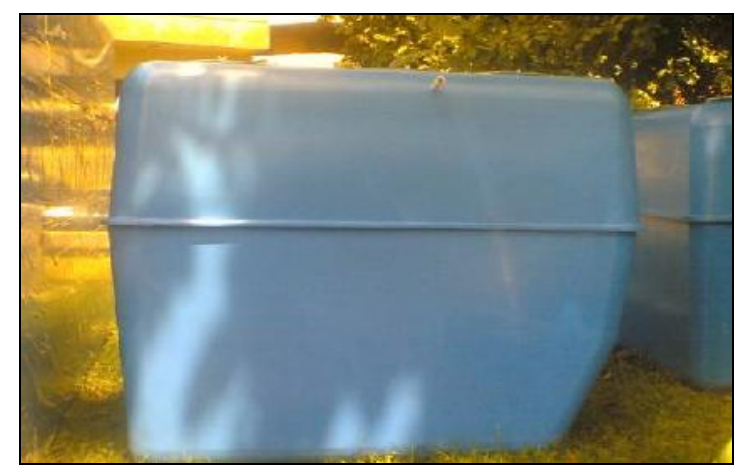

Gambar 15. Bahan pembuatan IPAL dari fiber glass

\section{PENUTUP}

Instansi pemerintah pusat dan daerah wajib memberikan pelayanan publik prima dan berkualitas. Beberapa elemen penting pelayanan tersebut, antara lain penyelenggaraan pelayanan yang baik, adanya standar pelayanan, transparansi dan akuntabilitas pelayanan, dan penegakan prinsip-prinsip tata pemerintahan yang baik, dalam kerangka reformasi birokrasi aparat negara.

Informasi teknologi pengelolaan air bersih dan teknologi pengolahan air limbah perlu disediakan dan diumumkan pada papan pengumuman yang tersedia, media cetak (surat kabar lokal dan nasional serta media sejenis), media elektronik (website), forum diskusi publik dan media lainnya yang memungkinkan masyarakat mendapatkan akses pada informasi dimaksud.

Penting dicatat, untuk memberikan pelayanan publik yang baik, perlu didukung oleh perubahan mind-set dan cultural-set, serta penegakan unsur-unsur integritas, moralitas, etika, sosialisasi prinsip-prinsip good governance dan reformasi birokrasi, keteladanan, dan budaya kerja yang baik, efektif, efisien, dan produktif.

\section{DAFTAR PUSTAKA}

1. Erry Riyana Hardjapamekas, "Transparency and Accountability - Continuing Improvement in Performance Public Sector Management." Makalah dipresentasikan pada "Workshop on The Regional Forum on Reinventing Government in Asia: Towards Transparent and Accountable Governance", diselenggarakan oleh United Nations Department of Economics and Social Affairs (UNDESA) New York bekerjasama dengan Kementerian Negara Pendayagunaan Aparatur Negara, United Nations Governance Center (UNGC) Korea, dan United Nations Development Programme (UNDP), Jakarta, 14-16 November 2007.

2. Ismail Mohamad, "Reforms to Build and Sustain Transparency and Accountability in the Public Sector, The Indonesian Experience", UNDESA bekerjasama dengan Kementerian PAN, UNGC, dan UNDP, Jakarta,14-16 November 2007.

3. Keputusan Menteri Negara Pendayagunaan Aparatur Negara Nomor 63/KEP/M.PAN/ 7/2003 Tentang Pedoman Umum Penyelenggaraan Pelayanan Publik.

4. Keputusan Menteri Negara Pendayagunaan Aparatur Negara Nomor KEP/26/M.PAN/ 2/2004 Tentang Petunjuk Teknis Transparansi dan Akuntabilitas Dalam Penyelenggaraan Pelayanan Publik.

5. Komarudin, "Transparency and Accountability in Local Governance", UNDESA bekerjasama dengan Kementerian PAN, UNGC, dan UNDP, Jakarta, 14-16 November 2007.

6. Komarudin, "Meningkatkan Pemahaman tentang Rancangan Undang-Undang Tentang Pelayanan Publik", Jakarta, April 2009.

7. Satmoko Yudo, "Pengelolaan Air Minum Berbasis Masyarakat", Jurnal Air Indonesia, PTL-BPPT, 2005

8. Lembaga Administrasi Negara, "Strategi Peningkatan Kualitas Pelayanan Publik", Jakarta, 2006.

9. Mohamad Emir Mavani, "Transparency and Accountability", UNDESA bekerjasama dengan Kementerian PAN, UNGC, dan UNDP, Jakarta,14-16 November 2007.

10. Nusa Idaman Said dan Satmoko Yudo, "Masalah dan Strategi Penyediaan Air Bersih di Indonesia". Makalah dalam buku "Teknologi Pengolahan Air Minum-Teori dan Pengalaman Praktis", Pusat Teknologi Lingkungan BPPT, 2008.

11. Nusa Idaman Said dan Arie Herlambang, "Pengolahan Air Bersih dengan Proses Saringan Pasir Lambat". Makalah 
dalam buku "Teknologi Pengolahan Air Minum-Teori dan Pengalaman Praktis", Pusat Teknologi Lingkungan BPPT, 2008.

12. Pan Suk Kim, "How to Build and Sustain Transparency and Accountability in Public Sector", Yonsei University, Seoul, UNDESA bekerjasama dengan Kementerian PAN, UNGC, dan UNDP, Jakarta, 14-16 November 2007.

13. Peraturan Pemerintah Nomor 65 Tahun 2005 Tentang Pedoman Penyusunan dan Penerapan Standar Pelayanan Minimal.

14. Peraturan Menteri Negara Pendayagunaan Aparatur Negara Nomor PER/20/M.PAN/4/ 2006 Tentang Pedoman Penyusunan Standar Pelayanan Publik.

15. Peraturan Menteri Negara Pendayagunaan Aparatur Negara Nomor PER/04/M.PAN/ 4/2007 Tentang Pedoman Umum Formulasi, Implementasi, Evaluasi Kinerja dan Revisi Kebijakan Publik di Lingkungan Lembaga Pemerintah Pusat dan Daerah.

16. Peraturan Gubernur DKI Jakarta Nomor 122 tahun 2005 Tentang Pengelolaan Air Limbah Domestik di Provinsi Daerah Khusus Ibukota Jakarta. 